\title{
PROSPECTIVE STUDY OF INJURIES OCCURRED DURING BRAZILIAN FOOTBALL CHAMPIONSHIP IN 2019
}

\section{ESTUDO PROSPECTIVO DAS LESÕES ESPORTIVAS OCORRIDAS DURANTE O CAMPEONATO BRASILEIRO DE FUTEBOL EM 2019}

\author{
Gustavo Gonçalves arliani ${ }^{1}$ (10, Paulo Henrique Schmidt Lara ${ }^{1}$ (1), Gabriel Furlan Margato ${ }^{1}$ (1), \\ Diogo Cristiano Netto ${ }^{2}$ (1), Molsés Cohen ${ }^{1}$ (1), Jorge Roberto Pagura ${ }^{3}$ (1)
}

1. Sports Traumatology Center, Escola Paulista de Medicina, São Paulo, SP, Brazil.

2. Brazilian Football Confederation, Rio de Janeiro, RJ, Brazil.

3. ABC Medical School (FMABC), Santo André, SP, Brazil.

\section{ABSTRACT}

Objective: To determine the incidence and risk factors for injuries that occurred during the matches of the Brazilian Football Championship. Methods: A prospective study was carried out with the collection of data referring to injuries that occurred during the 2019 Brazilian Football Championship. The injuries were recorded by the responsible physician of each team, through an online injury mapping system. Results: Among the 645 athletes who were included in the study, 214 (33.2\%) of the players had at least one injury during the tournament. In total, 257 injuries were recorded during the Brazilian Championship, with an average of 0.68 injuries per game. $59.1 \%$ of the injured athletes were over 26 years old. The most common type of injury was muscle strain (37.7\%) and forwards were the most affected (33.6\%). Conclusion: Muscle injuries were the most frequent in the tournament, with the thigh muscles being the most affected. Most of the affected players were over 26 years old, there were 20.5 injuries for every 1000 hours of play and the incidence of injuries was approximately $33 \%$, with attackers being the most affected (33.6\%). Level of Evidence III, Study of nonconsecutive patients; without consistently applied reference "gold" standard.

Keywords: Athlete. Football. Athletic Injuries.

\section{RESUMO}

Objetivo: Determinar a incidência e fatores de risco para as lesões ocorridas durante as partidas do Campeonato Brasileiro de Futebol. Métodos: Realizou-se um estudo prospectivo com coleta dos dados referentes às lesões ocorridas durante o Campeonato Brasileiro de Futebol de 2019. O registro das lesões foi realizado pelo médico responsável de cada equipe, por meio de um sistema online de mapeamento de lesões. Resultados: Dentre os 645 atletas que foram incluídos no estudo, 214 (33,2\%) dos jogadores apresentaram pelo menos uma lesão durante o torneio. No total, foram registradas 257 lesões durante o Campeonato Brasileiro, com média de 0,68 lesões por partida. 59,1\% dos atletas lesionados tinham mais de 26 anos. O tipo de lesão mais comum foi o estiramento muscular (37,7\%) e os atacantes foram os mais acometidos (33,6\%). Conclusão: Lesões musculares foram as mais frequentes no torneio, sendo a musculatura da coxa a mais acometida. A maioria dos jogadores afetados tinham mais de 26 anos, houve 20,5 lesões para cada 1000 horas de jogo e a incidência de lesões foi de aproximadamente 33\%, com os atacantes sendo os mais afetados (33,6\%). Nível de Evidência III, Estudo de pacientes não consecutivos; sem padrão de referência "ouro" aplicado uniformemente.

Descritores: Atleta. Futebol. Lesões Esportivas.

Citation: Arliani GG, Lara PHS, Margato GF, Netto DC, Cohen M, Pagura JR. Prospective study of injuries occurred during Brazilian football championship in 2019. Acta Ortop Bras. [online]. 2021;29(4):207-210. Available from URL: http://www.scielo.br/aob.

\section{INTRODUCTION}

Soccer is the most practiced sport in Brazil and one of the most practiced worldwide. ${ }^{1}$ When the sport is performed professionally, athletes are physically demanding, which can increase their predisposition to injuries. ${ }^{1,2}$ The risk of injuries in soccer is relatively high when compared to other sports and activities, with incidence rates ranging from 15 to 70 injuries per 1000 hours of exposure in games. ${ }^{1-9}$ The Brazilian soccer championship is one of the main championships in the world, with highly competitive athletes and clubs. ${ }^{3}$ Due to the degree of national and world relevance, whether sporting or economic, excellence and maximum individual and collective performance of teams are sought in order to obtain the best results. Thus, there has been greater interest of clubs and confederations in physical preparation and improvement of preventive activities for injuries aimed at players. ${ }^{4}$ Epidemiological studies on football injuries in Brazil are scarce. Brazil is a continental size country with a very different climate and conditions in relation to Europe and the United States, which could justify differences in patterns and risk factors for injuries. ${ }^{1,10}$

All authors declare no potential conflict of interest related to this article.

The study was conducted at Centro de Traumatologia do Esporte da Escola Paulista de Medicina.

Correspondence: Paulo Henrique Schmidt Lara. R. Estado de Israel 636, São Paulo, SP, Brazil, 04022001. phslara@gmail.com

Article received on 07/29/2020, approved on 09/24/2020. 
Therefore, our study aimed to conduct a prospective assessment of injuries that occurred in professional soccer players of the Brazilian A Series championship in 2019, analyzing and correlating their characteristics with possible risk factors.

\section{MATERIALS AND METHODS}

This is a prospective study carried out with an electronic questionnaire previously developed and approved by the medical committee of the Brazilian Football Confederation, being used in the mapping of injuries in Brazilian soccer since 2016. The recording of injuries was performed by the physician responsible for each team, through an online injury mapping system available on the physician's portal of the Brazilian Football Confederation (CBF) (portaldomedico. cbf.com.br). The questionnaire was answered by the doctors of the teams that compete in the A series of the Brazilian soccer championship after each round of games in the 2019 championship. The questionnaire consisted of several questions about the match characteristics, the affected athlete and the injury. All athletes regularly enrolled in the 2019 A series Brazilian championship who participated in at least 1 game of the tournament were included in the study. Athletes enrolled by clubs that did not play in at least one game were excluded from the study. The definition of injury adopted was proposed by Fuller et al. ${ }^{11}$ for the 2005 FIFA consensus, according to which an injury is "any physical complaint resulting from a football match, regardless of the need for medical assistance, attention or loss of time in football activities". To assess the risk of injury, we calculated the incidence of injury, which is expressed as the number of injuries per 1000 hours of exposure. The following formula was used to calculate exposure by correspondence: Exposure $=$ number of matches in the championship $\times$ number of players participating in matches $\times$ match duration in minutes $/ 60$. To calculate the incidence of injuries, the following formula was used: Incidence $=$ number of injuries in matches $\times 1000$ hours/ exposure time. Measures of central tendency and dispersion were expressed as means and standard deviation (SD) for continuous variables with symmetrical distribution, and as medians, minimum and maximum values for those with asymmetrical distribution. Categorical variables are expressed in their absolute and relative values. The estimate of difference between categorical variables was performed using the test for equality of two proportions and chi-square. The odds ratio (OR) was calculated to quantify the risk of injuries associated with some study variables. For all tests, a minimum significance level of $5 \%$ and a $95 \%$ confidence interval were considered.

This study was approved by the Research Ethics Committee of the Federal University of São Paulo/Escola Paulista de Medicina (567236616.3.0000.5505).

\section{RESULTS}

A total of 645 players participated in at least one match of the 2019 Brazilian championship and were included in this study. The tournament started in April and ended in December 2019, totaling 38 rounds, 380 matches and 20 participating professional teams. The average age of athletes participating in the championship was 26.1 years. Among the injured athletes, we found an average age of 26.9 years. Among the 645 athletes that were included in the study, 214 (33.2\%) of players had some kind of injury during the tournament. In total, 257 injuries were reported, with an average of 0.68 injuries per match. The incidence of injuries in the Brazilian first division championship in 2019 was 20.5 injuries for every 1,000 hours of game. The relationship between injuries and the time the matches were played (morning, afternoon or evening) did not show significant differences, which can be seen in Table 1.
Table 1. Ratio of injuries $\times$ time of matches.

\begin{tabular}{c|c|c|c|c|c|c}
\hline \multirow{2}{*}{} & \multicolumn{2}{|c|}{ With Injury } & \multicolumn{2}{c|}{ Without Injury } & \multicolumn{2}{c}{ Total } \\
\cline { 2 - 7 } & $\mathbf{N}$ & $\%$ & $\mathbf{N}$ & $\%$ & $\mathbf{N}$ & $\%$ \\
\hline Morning & 10 & $3.9 \%$ & 36 & $6.5 \%$ & 46 & $5.7 \%$ \\
\hline Afternoon & 94 & $36.6 \%$ & 171 & $30.8 \%$ & 265 & $32.6 \%$ \\
\hline Evening & 153 & $59.5 \%$ & 349 & $62.8 \%$ & 502 & $61.7 \%$ \\
\hline Total & 257 & $31.6 \%$ & 556 & $68.4 \%$ & 813 & $100 \%$ \\
\hline
\end{tabular}

$p>0.05$

Of the total number of injuries, 49.4\% (127 injuries) occurred in players from the home team, however, we did not find a significant difference between injuries that occurred in the home and visiting teams, which can be seen in Table 2.

\begin{tabular}{c|c|c|c|c|c|c}
\hline \multirow{2}{*}{ Table 2. Ratio of injuries $\times$ home/visiting team. } & \multicolumn{2}{|c|}{ With Injury } & \multicolumn{2}{c|}{ Without Injury } & \multicolumn{2}{|c}{ Total } \\
\cline { 2 - 7 } & $\mathbf{N}$ & $\%$ & $\mathbf{N}$ & $\%$ & $\mathbf{N}$ & $\%$ \\
\hline Home & 127 & $49.4 \%$ & 280 & $50.4 \%$ & 407 & $50.1 \%$ \\
\hline Visiting & 130 & $50.6 \%$ & 276 & $49.6 \%$ & 406 & $49.9 \%$ \\
\hline Total & 257 & $31.6 \%$ & 556 & $68.4 \%$ & 813 & $100 \%$ \\
\hline
\end{tabular}

$p>0.05$

Regarding the age of the injured players, we observed that most of them (59.1\%) were over 26 years old. ( $p<0.001)$ Regarding the position of injured athletes, we found a majority of forwards (33.6\%), followed by midfielders (19\%). With regard to the distance covered by the teams before the matches, most injuries occurred in matches played at home (50.8\%). However, in away matches, most injuries occurred in games in which the visiting club traveled more than 800 kilometers $(\mathrm{km})$ to the home club city (35\%). The distribution of injuries in relation to the championship round in which they occurred is shown in Figure 1.

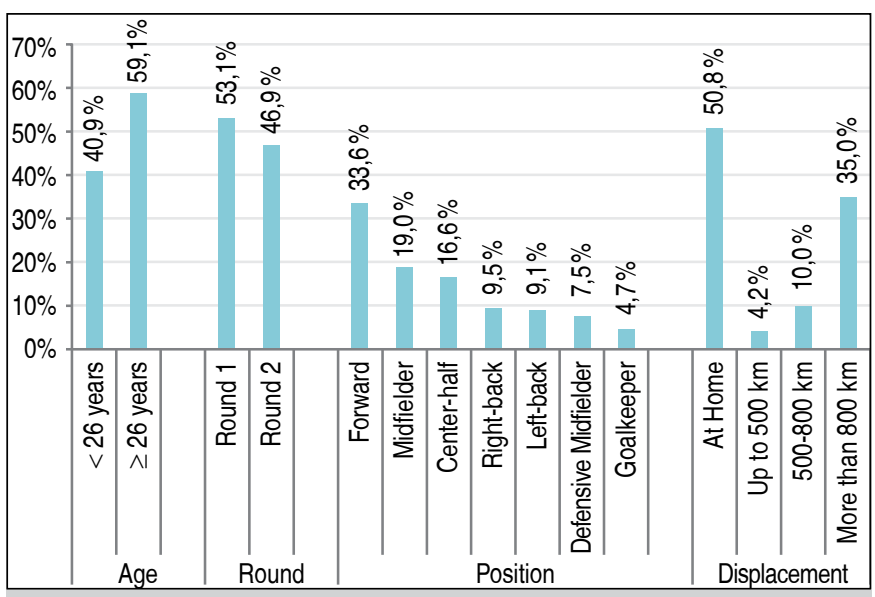

Figure 1. Distribution of variables $\times$ injured players

Around $62 \%$ of the injuries (159) occurred without contact, with the thigh (40.5\%), head (14\%), ankle (11.7\%) and knee (11.3\%) being the most common body areas affected by injuries. Approximately $60 \%$ of injuries occurred in the midfield region, with the majority of injuries occurring in the last 15 minutes of the first half (23.6\%) and in the central third of the second half of the match (21.7\%), which can be seen in Figure 2. 


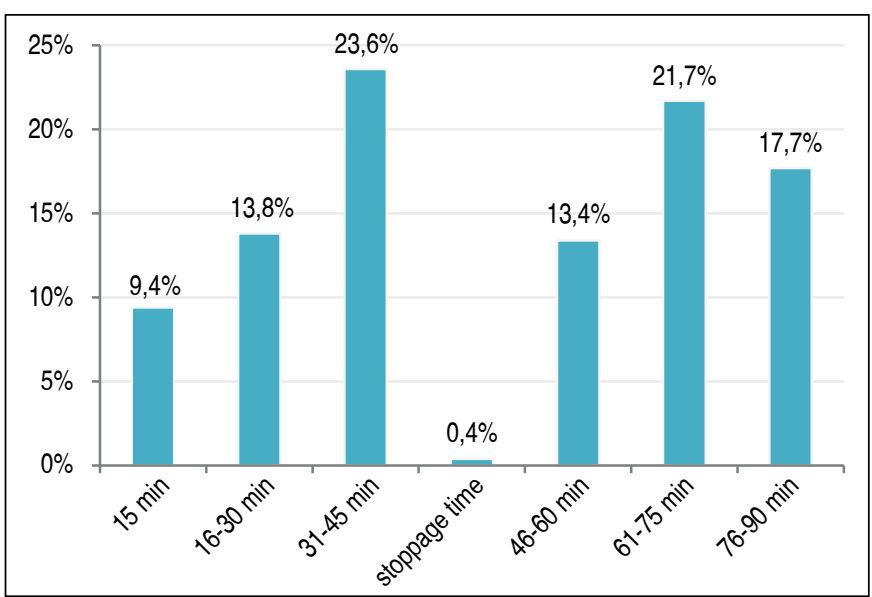

Figure 2. Distribution of the moment of injuries.

The most common types of injuries that occurred in the 2019 Brazilian championship were: muscle strains (37.7\%), bruises (19.1\%) and sprains (15.6\%). Strain of the hamstring (15.6\%) and adductor (10.9\%) muscles were the two most common diagnoses. Recurrence of injury occurred in $8 \%$ of cases.

\section{DISCUSSION}

In the 2019 Brazilian championship, about a third of the athletes had some kind of injury during the championship, with an average of 0.68 injuries per match (20.5 injuries per 1000 hours of game). There were practically similar data between injuries in home and visiting teams. The most affected players were forwards and the most common injuries were thigh muscle strains. About half of the injuries occurred in matches at home, but injuries occurred away from home were more common in matches where there was a travel distance greater than $800 \mathrm{~km}$.

The mean age of injured athletes in the study was 26.9 years, above that described in previous studies. ${ }^{10,12}$ Almost $60 \%$ of patients were over 26 years of age. There was an average of 0.68 injuries per match, below the number reported in other studies, such as the one by Pedrinelli et al. ${ }^{5}$ and Junge \& Dvorak ${ }^{13}$ who found 2.4 injuries per match. This difference may be due to the fact that our study evaluated a larger number of players and due to the longer championship model with more matches.

The incidence of injuries in the Brazilian championship in the first division in 2019 was 20.5 injuries for every 1,000 hours of game. Value that is within the variation found in the literature, which ranges from 15 to 70 injuries per 1,000 hours of game.1-9 These values have this considerable variation due to differences in study designs, data collection methods and injury definitions. ${ }^{14}$ Most injuries occurred in the first round. There is a need for new studies that also assess this aspect, as it is expected that there would be a higher prevalence of injuries in the second round, due to the fact that most injuries are muscular, which are related to muscle fatigue, which in a general way is more common towards the end of the season.

Regarding the match period, there was no statistical difference in matches played in the morning, afternoon or evening. One could expect a higher incidence of injuries in the morning and afternoon, when there are usually higher temperatures, but this was not found in our study.

It was also evaluated whether there would be any difference in relation to the number of injuries and the fact that the team is home or visiting, but there was no statistical difference. A hypothesis suggested would be that there would be a higher incidence of injuries in the visiting team due to the displacement, opposing fans, worse sleep conditions and unusual grass. No previous study performed this assessment.

Forwards were the most affected, similar to previous studies, ${ }^{1-4}$ but in other studies midfielders were the most affected. ${ }^{15-17}$ One hypothesis for this difference is that these studies did not subdivide midfielders into defensive (holding or anchor) and attacking midfielders.

The majority of injuries occurred in matches at home and in those that occurred away from home, the majority occurred in matches where more than $800 \mathrm{~km}$ were covered. In the study by Bengtsson et al. ${ }^{18}$ that evaluated 14 consecutive seasons of UEFA clubs there was a greater number of injuries when there was less than three days of rest between matches. This may be related to the fact that there is a higher incidence of injuries in matches with displacements above $800 \mathrm{~km}$, in which athletes have a shorter rest time between matches.

Only about $40 \%$ of injuries occurred after contact, a figure below previous studies in which $50-70 \%$ of injuries occurred after contact. ${ }^{1,5-7}$ It is noteworthy that the most common injury in this study was muscle injury, which most often occurs without contact between the athletes, which would justify this decrease in the percentage of injuries that occurred after contact.

The thigh was the most affected site (40.5\%), followed by the head $(14 \%)$, which is similar to previous studies. ${ }^{5,9,15,19-22}$ Because the two most common injuries were muscle strains of the hamstrings and adductors, the thigh was the site most affected by injuries in the present study.

$60 \%$ of the injuries occurred in midfield, we did not find any study in the literature that evaluated this aspect. This is expected, since most of the time the ball is in play it is in midfield and with that there is a higher percentage of injuries in this field region.

In our study, the majority (23.6\%) of injuries occurred in the final 15 minutes of the first half, followed by the central third of the second half $(21.7 \%)$, similar to what was found in our previous study, ${ }^{1}$ but different from studies in which the majority of injuries occurred in the final 30 minutes of the game..$^{5,6}$

The most common type of injury was muscle strain (37.7\%), with the hamstring (15.6\%) and adductor (10.9\%) muscles being the most affected, which is similar to several studies previously carried out that found the same results. ${ }^{1-4,9}$ In the study by Ekstrand et al., ${ }^{23}$ which evaluated 2299 players from European clubs between 2001 and 2009, about a third of the injuries were muscle injuries, and among these, hamstring muscle injuries were the most common, as in our study. Junge \& Dvorák ${ }^{24}$ assessed injuries that occurred during the 2014 World Cup in Brazil and the most common injury was muscle injury in the thigh and the authors recommended interventions to prevent non-contact lower limb injuries, which should be part of the soccer clubs' training routine.

A study limitation is the possibility of information bias, as it may have been modified or even omitted by the clubs' physicians. In addition, the study only assessed acute injuries that occurred during matches and did not assess injuries sustained during training and non-sport-related illnesses. Another limitation is that the exposure time was calculated based on 22 players and 90 minutes per match. A more accurate method would be to consider the stoppage time or actual duration of each match and the number of minutes of exposure for each individual player. The information obtained in this study is important in preventing new injuries in soccer. The data 
will allow the medical teams of clubs and federations to develop preventive programs to reduce the incidence of injuries in soccer.

\section{CONCLUSION}

Muscle injuries were the most frequent in the tournament, with the majority affecting the forwards and thigh muscles. The majority of affected players were over the age of 26 , there were 20.5 injuries for every 1,000 hours of game and the incidence of injuries was approximately $33 \%$.

\section{ACKNOWLEDGMENTS}

We would like to thank the Brazilian Football Confederation and the physicians of the A-series teams who assisted in providing data for the production of this study.

AUTHORS' CONTRIBUTION: Each author contributed individually and significantly to the development of this article. GGA: Substantial contribution to the study design, writing and final approval; PHSL: writing and final approval; GFM: substantial contribution to the study analysis, writing; DCN: substantial contribution to the study analysis; MC: substantial contribution to the study design and final approval; JRP: substantial contribution to the study design, writing and final approval.

\section{REFERENCES}

1. Arliani GG, Lara PHS, Astur DC, Pedrinelli A, Pagura JR, Cohen M. Prospective evaluation of injuries ocurred during a professional soccer championship in 2016 in São Paulo, Brazil. Acta Ortop Bras. 2017;25(5):212-5.

2. Netto DC, Arliani GG, Thiele ES, Cat MNL, Cohen M, Pagura JR. Prospective evaluation of injuries occurred during the Brazilian Soccer Championship in 2016. Rev Bras Ortop. 2019;54(3):329-34.

3. Arliani GG, Lara PHS, Astur DC, Pedrinelli A, Pagura JR, Cohen M. Orthopaedics injuries in male professional football players in Brazil: a prospective comparison between two divisions. Muscles Ligaments Tendons J. 2018;7(3):524-31.

4. Moraes ER, Arliani GG, Lara PHS, Silva EHR, Pagura JR, Cohen M. Orthopedic injuries in men's professional soccer in Brazil: prospective comparison of two consecutive seasons 2017/2016. Acta Ortop Bras. 2018;26(5):338-41.

5. Pedrinelli A, Cunha Filho GAR, Thiele ES, Kullak OP. Estudo epidemiológico das lesões no futebol profissional durante a Copa América de 2011, Argentina. Rev Bras Ortop. 2013;48(2):131-6.

6. Aoki H, O'Hata N, Kohno T, Morikawa T, Seki J. A 15-year prospective epidemiological account of acute traumatic injuries during official professional soccer league matches in Japan. Am J Sports Med. 2012;40(5):1006-14.

7. Pangrazio O, Forriol F. Epidemiology of soccer players traumatic injuries during the 2015 America Cup. Muscles Ligaments Tendons J. 2016;6(1):124-30.

8. Smpokos E, Mourikis C, Theos C, Linardakis M. Injury prevalence and risk factors in a Greek team's professional football (soccer) players: a three consecutive seasons survey. Res Sports Med. 2019;27(4):439-51.

9. Jones A, Jones G, Greig N, Bower P, Brown J, Hind K, Francis P. Epidemiology of injury in English Professional Football players: A cohort study. Phys Ther Sport. 2019;35:18-22.

10. Cohen M, Abdalla RJ, Ejnisman B, Amaro JT. Lesões ortopédicas no futebol. Rev Bras Ortop. 1997;32(12):940-4.

11. Fuller CW, Ekstrand J, Junge A, Andersen TE, Bahr R, Dvorak J, et al. Consensus statement on injury definitions and data collection procedures in studies of football (soccer) injuries. Clin J Sport Med. 2006;16(2):97-106.
12. Fachina RJFG, Andrade MS, Silva FR, Waszczuk-Junior S, Montagner PC, Borin JP, Lira CAB. Descriptive epidemiology of injuries in a Brazilian premier league soccer team. Open Access J Sports Med. 2013;4:171-4.

13. Junge A, Dvorak J. Injury surveillance in the World Football Tournaments 1998-2012. Br J Sports Med. 2013;47(12):782-8.

14. Arliani GG, Belangero PS, Runco JL, Cohen M. The Brazilian Football Association (CBF) model for epidemiological studies on professional soccer player injuries. Clinics (Sao Paulo). 2011;66(10):1707-12.

15. Morgan BE, Oberlander MA. An examination of injuries in major league soccer The inaugural season. Am J Sports Med. 2001;29(4):426-30.

16. Noya Salces J, Gómez-Carmona PM, Gracia-Marco L, Moliner-Urdiales D, Sillero-Quintana M. Epidemiology of injuries in First Division Spanish football. J Sports Sci. 2014;32(13):1263-70.

17. Hwang-Bo $\mathrm{K}$, Joo $\mathrm{CH}$. Analysis of injury incidences in the Korea national men's soccer teams. J Exerc Rehabil. 2019;15(6):861-6.

18. Bengtsson $\mathrm{H}$, Ekstrand J, Waldén $M$, Hägglund $M$. Muscle injury rate in professional football is higher in matches played within 5 days since the previous match: a 14-year prospective study with more than 130000 match observations. Br J Sports Med. 2018;52(17):1116-22.

19. Schmidt-Olsen S, Bünemann LK, Lade V, Brassøe JO. Soccer injuries of youth. Br J Sports Med. 1985;19(3):161-4.

20. McMaster WC, Walter M. Injuries in soccer. Am J Sports Med. 1978;6(6):354-7.

21. Ekstrand J, Nigg BM. Surface-related injuries in soccer. Sports Med. 1989;8(1):56-62.

22. Astur DC, Novaretti JV, Uehbe RK, Arliani GG, Moraes ER, Pochini AC, et al. Muscle injury: current perspectives and trends in Brazil. Rev Bras Ortop. 2014;49(6):573-80.

23. Ekstrand J, Hägglund M, Waldén M. Epidemiology of muscle injuries in professional football (soccer). Am J Sports Med. 2011;39(6):1226-32.

24. unge A, Dvořák J. Football injuries during the 2014 FIFA World Cup. Br J Sports Med. 2015;49(9):599-602. 